\title{
Unsafe abortion among secondary school girls in a local authority in South-South Nigeria
}

\author{
Matthias G. Abah ${ }^{1 *}$, Emem E. Bassey ${ }^{1}$, Emmanuel B. Edu $^{2}$, Okupa D. Ovie $^{2}$
}

${ }^{1}$ Department of Obstetrics and Gynecology, College of health sciences, University of Uyo, Nigeria
${ }^{2}$ Department of Obstetrics and Gynecology, University of Uyo Teaching Hospital, Nigeria

Received: 13 July 2020

Accepted: 07 August 2020

\section{*Correspondence:}

Dr. Matthias G. Abah,

E-mail: gabriel.abah@rocketmail.com

Copyright: (c) the author(s), publisher and licensee Medip Academy. This is an open-access article distributed under the terms of the Creative Commons Attribution Non-Commercial License, which permits unrestricted non-commercial use, distribution, and reproduction in any medium, provided the original work is properly cited.

\begin{abstract}
Background: Voluntary abortion for social reasons is illegal in Nigeria; however, the practice remains mostly clandestine and unsafe with varying consequences and determinants yet to be studied in all settings.

Methods: A descriptive cross-sectional study design was used to assess the prevalence, practice and determinants of termination of pregnancy amongst 119 female Secondary School students in South-South Nigeria.

Results: The prevalence of abortion was $57.1 \%$. Most of the students were above 18years (58.8\%), Christian (95.8\%) and of rural residence $(66.4 \%)$. While $58.8 \%$ had experienced an unwanted pregnancy, $61.4 \%$ had used some form of contraceptive with condom being the commonest (39.5\%). Most $(89.1 \%$ ) have heard of abortions while $67.6 \%$ and $16.2 \%$ have had abortions once and twice respectively with the top reasons for abortion being that they were still in school $(33.8 \%)$, too young $(25.9 \%)$ and to avoid shame or stigma associated with the pregnancy $(11.7 \%)$. Dilation and curettage was the predominant method employed (40.2\%) mainly by medical doctors $(34.1 \%$ and pharmacists $(35.6 \%)$ while 51 (75\%) had post-abortal complaints such as pain $(41.2 \%)$ and bleeding $(21.6 \%)$. There was a significant association between having an abortion and place of residence (rural more than urban), $(\mathrm{p}=0.04)$, being pregnant more than once $(\mathrm{p}<0.001)$, mothers` level of education $(\mathrm{p}=0.03)$, fathers` level of education $(\mathrm{p}=0.02)$ and mothers occupation $(\mathrm{p}=0.04)$.

Conclusions: The prevalence of abortion is high and complicated by high morbidity rate despite a higher contraceptive prevalence rate whose major determinants were the socio-demographic characteristics of the parents. There is a need for early sex education from parents as this can influence abortion perception and practice in later years.
\end{abstract}

Keywords: Abortion, Adolescents, Determinants, Prevalence, Practice

\section{INTRODUCTION}

The termination of pregnancy before the gestational age of foetal viability may be spontaneous or induced. The voluntary induction of abortion in some countries including Nigeria is considered a criminal offence except when it is performed to save the woman's life. ${ }^{1}$ The law governing the practice of abortion in Nigeria is restrictive in nature and this has driven the performance of induced abortions for social reasons underground. ${ }^{2,3}$ As a result, most women seeking termination of pregnancy do so clandestinely in environments lacking minimal standards and often by persons lacking the need skills or both. ${ }^{4}$

About 210 million pregnancies occur annually worldwide, out of this number, about 80 million $(38 \%)$ are unplanned and 46 million $(22 \%)$ end in abortions. ${ }^{5} \mathrm{~A}$ study by the Gutttmacher institute and Ipas(organisation) reported that at-least 1.2 million induced abortions occur every year in Nigeria. ${ }^{6}$ Abortions in sub-Saharan Africa are often performed in unsafe environments with the mortality as high as $20-40 \% .^{7}$ Unsafe abortion constitutes 
$56 \%$ of all abortions in developing countries. ${ }^{8,9}$ A study in Nigeria reported that Abortion-related mortality accounted for $11.8 \%$ of all maternal deaths which were mainly from sepsis and haemorrhage from unsafe procedures. ${ }^{10}$ Unsafe abortion is associated with early complications such as sepsis, haemorrhage requiring blood transfusion, uterine and bowel perforation, pelvic abscess, endotoxic shock and renal failure; and long term morbidities such as chronic pelvic pain, cervical incompetence, ectopic pregnancy and infertility. ${ }^{11}$ The burden of unsafe abortion may be higher than stated because many women do not get to access care in public hospitals.

The burden of abortion complications has been on the increase because of a sexually permissive society that is not matched by contraceptive usage. Contraceptive usage in Nigeria is low with a prevalence of $11-13 \% .{ }^{12}$ Despite the reluctance to use contraceptives, many women who conceive outside wedlock are unwilling to continue with the pregnancy because of cultural and religious stigmatization. Hence the morbidity and mortality from induced abortion complications is inversely proportional to the contraceptive usage rate as a rise in contraceptive use or effectiveness invariably leads to a decline in induced abortion and vice versa. ${ }^{7}$

The adolescent population accounts for about 1.2 billion people or 1 in 6 of the world's population and for more than 1.1 million deaths in 2016, mostly from preventable or treatable causes including complications of pregnancy and childbirth arising from unprotected sex and underutilisation of contraceptives. ${ }^{13}$ Studies have shown that $14 \%$ of all unsafe abortions in low- and middleincome countries are procured by women aged 15-19 years while more than $50 \%$ of the global abortion-related mortalities occur in the 15-24 years age group in Africa. ${ }^{14,15}$ The centre for disease control and prevention (CDC) reported that induced abortion among in the 1519 years age-group accounted for $14.6 \%$ of all abortions or 12 abortions per 1000 adolescents in the united states of America. ${ }^{16}$ The determinants of the practice of induced abortion found in some studies include parental residence, sexual health education, alcohol consumption, poverty, illiteracy, grand multiparity and noncontraceptive use. ${ }^{17,18}$

However, to the best of authors knowledge, no published article focused on induced abortion and its determinants among that secondary school students has emanated from this state. The aims of this study therefore were to assess the magnitude, the practice and the determining factors for induced abortion among students in selected secondary schools in a local Government area in Southsouth, Nigeria. Authors believe this will not only add to the body of knowledge on induced abortion among adolescents, but may produce insights to developing strategies and intervention to mitigate the practice and complications associated with the unsafe abortion in this region.

\section{METHODS}

The South-South region is one of the six geopolitical zones in Nigeria where Akwa Ibom state is located. Akwa Ibom state is made-up of thirty-one local government areas. Nsit Ubium is one of the local government areas in the Uyo senatorial district of the state consisting of two clans: Nsit and Ubium with 31 and 33 villages respectively.

The local government area has a land mass of 242.942 $\mathrm{km}^{2}$ and a total population of 127,083 people as at the 2006 National census projected to 178,500 in $2016 .{ }^{19}$ Nsit Ubium is an oil-producing area, with deposits of clay, gravel and fine sand as well as Nickel deposits. The people are involved in many economic endeavours including farming, fishing and trading.

There are various health institutions (both government and private) at different levels to cater for the health needs of the people. The area also has numerous secondary and primary schools (both public and private).

A descriptive cross-sectional study design was used to assess the prevalence, practice and determinants of unsafe abortion amongst secondary school girls in Nsit Ubium local Government area of Akwa Ibom state, South south Nigeria.

The study populations were SS2 and SS3 senior secondary (SS) school girls in Nsit Ubium local government area of Akwa Ibom state in South South Nigeria.

The minimum calculated sample size for this study was 95 adolescents. This was determined using a previous study by the Guttmacher Institute, Nigeria, published in 2015 with $3.3 \%$ incidence of abortion in Nigeria. ${ }^{20}$

The formula below was used to determine the minimum sample size for the study:

Fisher's formula ${ }^{21} \mathrm{n}=\frac{z^{2} p q}{d^{2}}$

Where:

$\mathrm{n}=$ minimum sampling size

$\mathrm{z}=$ standard normal deviate, usually constant given as 1.96

$\mathrm{p}=$ Prevalence of the factor from previous study $=3.3 \%$, $3.3 / 100, \mathrm{p}=0.333$

$\mathrm{q}=$ Probability of something not happening (given as 1 $\mathrm{p}, 1-0.333, \mathrm{q}=0.167$ )

$\mathrm{d}=$ degree of precision was (given as 0.052 )

By substitution,

$\mathrm{N}=\frac{1.96^{2}(0.333 \times 0.167)}{0.05^{2}}=\frac{3.8416 \times 0.05561}{0.0025}=\frac{0.2136}{0.0025}=85.44$ 
Allowing for a $10 \%$ non-response rate $=10 / 100 \times 85.44=$ $8.544+85=\mathrm{N}=94$

The minimum sample size of 94 was required for the study. However, 125 questionnaires were distributed to increase the strength and applicability of the findings.

\section{Sampling technique}

A simple random sampling technique was used to recruit respondents into the study. Two secondary schools were selected with one each representing Public and Private secondary schools based on their population among schools in the two clans in Nsit Ubium. At each school, every adolescent female in SS2 and SS3 who consented was given an opportunity to ballot until the number to be recruited proportionally from each school was obtained using simple random sampling technique. Either a 'yes' or a 'no' was written on pieces of papers and every adolescent in SS2 and SS3 classes in the schools balloted. Questionnaires were administered to those who pick 'yes' until the proportion of the measured sample size allotted to the school was obtained.

\section{Inclusion criteria}

All female students in senior secondary (SS) 2 and SS 3 who consented to participate in the study and picked a "yes" during the balloting process were included.

\section{Exclusion criteria}

Those who declined consent to participate in the study and those in lower classes and male students were excluded from the study.

\section{Data collection tool}

A structured closed and open-ended questionnaire designed strictly for this work was used. The questionnaire had 3 sections A, B, and C. Section A captured the respondents' socio-demographic data, section B consisted of the students` reproductive health practices, their knowledge and practice of abortion while section C captured complaint/complications associated with the practice of abortion. The questionnaire was pretested in a different population using students from a different school in the local government area and necessary corrections and adjustments made.

\section{Data collection procedure}

The schools (study area) were visited after obtaining necessary ethical clearance and the details of the study discussed with the school's administration and the students. The questionnaires were administered to eligible respondents who consented to it. Further guide when necessary was provided by research assistants. The duly completed copies of the questionnaires were retrieved the same day.

\section{Statistical analysis}

Data were cleaned, entered and analyzed using statistical package for social sciences (SPSS) for windows version 25.0. Results were presented in tables and charts. Descriptive statistics (mean and standard deviation) was performed for continuous variables and categorical using proportions. Chi-square test was used to test for association between two variables and level of significant was set at $\mathrm{p}<0.05$.

\section{RESULTS}

Of the 125 questionnaires administered to the students, 119 were correctly completed giving a response rate of 95.2\% which were analysed and formed the basis for subsequent discussion. The prevalence of abortion was $57.1 \%$. The majority of the students were above 18 years (58.8\%), Christians (95.8\%), of the Ibibio tribe (67.2\%) and resided within the rural part of the local government area $(66.4 \%)$. Most of their mothers had secondary level of education $(35.3 \%)$ and were self-employed (41.2\%) while the majority of their fathers had post-secondary education (44.5\%) and were civil servant (32.8\%). Most of the parents $(71.4 \%)$ were still married at the time (Table 1).

Table 1: Socio-demographic characteristics of respondents.

\begin{tabular}{|lll|}
\hline Characteristics & Frequency & Percent \\
\hline Age group & & 41.2 \\
\hline Less than 18 & 49 & 58.8 \\
\hline 18 and above & 70 & 95.8 \\
\hline Religion & 114 & 3.4 \\
\hline Christianity & 4 & 0.8 \\
\hline Islam & 1 & 67.2 \\
\hline Traditional worshipper & & 21.9 \\
\hline Tribe & 80 & 8.4 \\
\hline Ibibio & 26 & 2.5 \\
\hline Anang & 10 & \\
\hline Oron & 3 & \\
\hline Others & & \\
\hline Place of residence & & \\
\hline
\end{tabular}

Continued. 


\begin{tabular}{|lll|}
\hline Characteristics & Frequency & Percent \\
\hline Rural & 79 & 66.4 \\
\hline Urban & 40 & 33.6 \\
\hline Mothers occupation & & \\
\hline Self-employed & 49 & 41.2 \\
\hline Civil servant & 26 & 21.8 \\
\hline Unemployed & 21 & 17.7 \\
\hline Housewife & 20 & 16.8 \\
\hline Others & 3 & 2.5 \\
\hline Fathers occupation & & \\
\hline Civil servant & 39 & 32.8 \\
\hline Housewife & 30 & 25.2 \\
\hline Self employed & 29 & 24.4 \\
\hline Unemployed & 18 & 15.1 \\
\hline Others & 3 & 2.5 \\
\hline Mothers' educational level & & \\
\hline Primary & 21 & 17.7 \\
\hline Secondary & 42 & 35.3 \\
\hline Post-secondary & 36 & 30.3 \\
\hline No formal education & 20 & 16.8 \\
\hline Father educational level & & \\
\hline Primary & 11 & 9.2 \\
\hline Secondary & 44 & 37.0 \\
\hline Post-secondary & 53 & 44.5 \\
\hline No formal education & 11 & 9.2 \\
\hline Parents current marital status & & \\
\hline Single & 10 & 8.4 \\
\hline Married & 85 & 71.4 \\
\hline Divorced & 12 & 6.1 \\
\hline Separated & 8 & 3.4 \\
\hline Widowed & 4 & \\
\hline & & \\
\hline
\end{tabular}

Table 2: Reproductive health practices of respondents.

\begin{tabular}{|lll|}
\hline Characteristics & Frequency & Percent \\
\hline Ever had an unwanted pregnancy & & \\
\hline Yes & 70 & 58.8 \\
\hline No & 49 & 41.2 \\
\hline Number of unwanted pregnancies $(\mathbf{n}=\mathbf{7 0})$ & & \\
\hline 1 & 51 & 72.9 \\
\hline 2 & 14 & 20.0 \\
\hline 3 & 4 & 5.7 \\
\hline 4 & 1 & 1.4 \\
\hline Used some/ any contraception prior to pregnant?***(n=70) & \\
\hline Yes & 43 & 61.4 \\
\hline No & 27 & 38.6 \\
\hline Type of contraception used $(\mathbf{n}=\mathbf{4 3 )}$ & & \\
\hline Condom & 17 & 39.5 \\
\hline Tablets/pills & 10 & 23.3 \\
\hline Withdrawal & 8 & 18.6 \\
\hline Injectables & 6 & 14.0 \\
\hline Rhythm/safe method & 2 & 4.6 \\
\hline
\end{tabular}


Table 3: Abortion related practices of respondents.

\begin{tabular}{|c|c|c|}
\hline Characteristics & Frequency & Percent \\
\hline \multicolumn{3}{|c|}{ Ever heard of abortion (n=119) } \\
\hline Yes & 106 & 89.1 \\
\hline No & 13 & 10.9 \\
\hline \multicolumn{3}{|l|}{ Ever had an abortion } \\
\hline Yes & 68 & 57.1 \\
\hline No & 51 & 42.9 \\
\hline \multicolumn{3}{|c|}{ Number of abortions performed $(n=68)$} \\
\hline 1 & 46 & 67.6 \\
\hline 2 & 11 & 16.2 \\
\hline 3 & 3 & 4.4 \\
\hline Not specified & 8 & 11.8 \\
\hline \multicolumn{3}{|l|}{ Reasons for aborting $(\mathrm{n}=77)^{* *}$} \\
\hline Still in school & 26 & 33.8 \\
\hline Too young & 20 & 25.9 \\
\hline Shame & 9 & 11.7 \\
\hline Afraid of parents & 8 & 10.4 \\
\hline Afraid for her health & 6 & 7.8 \\
\hline Not ready for babies & 3 & 3.9 \\
\hline Partner denied responsibility & 2 & 2.6 \\
\hline Other reasons & 3 & 3.9 \\
\hline \multicolumn{3}{|c|}{ ***ome gave more than one reason } \\
\hline \multicolumn{3}{|c|}{ Methods of abortion $(\mathrm{n}=82) * * *$} \\
\hline $\mathrm{D}$ and $\mathrm{C}$ & 33 & 40.2 \\
\hline Injections & 24 & 29.3 \\
\hline Unknown tablets & 11 & 13.4 \\
\hline Herbs & 8 & 9.8 \\
\hline Put vaginal concoction & 2 & 2.4 \\
\hline Vigorous physical exercise & 1 & 1.2 \\
\hline Others & 3 & 3.7 \\
\hline \multicolumn{3}{|c|}{$* * *$ some gave more than one method } \\
\hline \multicolumn{3}{|c|}{ Personnel that performed the abortion $(\mathbf{n}=\mathbf{8 2}) * * * *$} \\
\hline Doctor & 28 & 34.1 \\
\hline Pharmacist & 21 & 25.6 \\
\hline Nurse/midwife & 13 & 15.9 \\
\hline Traditional practice & 7 & 8.5 \\
\hline Community health worker & 5 & 6.1 \\
\hline Others (relative/friends etc.) & 8 & 9.8 \\
\hline \multicolumn{3}{|c|}{$* * * *$ some gave multiples of personnel } \\
\hline \multicolumn{3}{|c|}{ Where did you effect the abortion } \\
\hline Hospital/clinic & 36 & 42.9 \\
\hline Pharmacy/chemist shop & 22 & 26.2 \\
\hline Maternity/TBA home & 12 & 14.2 \\
\hline Health centre & 10 & 11.9 \\
\hline Others & 4 & 4.8 \\
\hline \multicolumn{3}{|c|}{ Who paid for the procedure $(n=68)$} \\
\hline Partner & 17 & 25.0 \\
\hline Friend & 17 & 25.0 \\
\hline Respondent & 12 & 17.6 \\
\hline Mother & 10 & 14.7 \\
\hline Other family members & 8 & 11.8 \\
\hline Father & 3 & 4.4 \\
\hline Others & 1 & 1.5 \\
\hline
\end{tabular}


Table 4: Complaints after the procedure.

\begin{tabular}{|lcc|}
\hline Characteristics & Frequency & Percent \\
\hline Any complication from the procedure $(\mathbf{n = 6 8})$ & 51 & 75.0 \\
\hline Yes & 17 & 25.0 \\
\hline No & 24 & 42.1 \\
\hline Type of complaint $(\mathbf{n}=\mathbf{5 7}) * * * *$ & 26.3 \\
\hline Pain & 15 & 19.3 \\
\hline Bleeding & 11 & 10.5 \\
\hline Fever & 6 & 1.8 \\
\hline Foul smelling vaginal discharge & 1 & \\
\hline Others & & 58.8 \\
\hline ****some have multiple complains & 30 & 41.2 \\
\hline Given any treatment for the complications & 21 & \\
\hline Yes & 35 & 31.5 \\
\hline No & 24 & 13.2 \\
\hline After the abortion, were you given any contraceptive advice/contraception & \\
\hline No & 9 & 35.3 \\
\hline Yes & & 23.5 \\
\hline don't know & 24 & 14.7 \\
\hline How you felt after the abortion & 16 & 17.6 \\
\hline Guilty & 10 & 8.8 \\
\hline Relief & 12 & \\
\hline Regret & 6 & \\
\hline None & & \\
\hline Indifferent & & \\
\hline
\end{tabular}

Table 5: Association between selected characteristics and abortion status of respondents.

\begin{tabular}{|c|c|c|c|c|}
\hline \multirow{2}{*}{ Characteristics } & \multicolumn{2}{|c|}{ Ever aborted } & \multirow{2}{*}{ Total n (\%) } & \multirow{2}{*}{$\begin{array}{l}\text { Statistical tests and } \\
\text { values }\end{array}$} \\
\hline & Yes n (\%) & No n $(\%)$ & & \\
\hline \multicolumn{4}{|l|}{ Age group } & \multirow{3}{*}{$\begin{array}{l}X^{2}=3.54 \\
P=0.06\end{array}$} \\
\hline $10-17$ & $33(48.5)$ & $16(31.4)$ & $49(41.2)$ & \\
\hline 18 and above & $35(51.5)$ & $35(68.6)$ & $70(58.8)$ & \\
\hline \multicolumn{4}{|l|}{ Religion } & \multirow{4}{*}{$\mathrm{P}=0.13$} \\
\hline Christianity & $63(92.7)$ & $51(100.0)$ & $114(95.8)$ & \\
\hline Islam & $4(5.9)$ & $0(0.0)$ & $4(3.4)$ & \\
\hline Traditional worshipper & $1(1.5)$ & $0(0.0)$ & $1(0.8)$ & \\
\hline \multicolumn{4}{|l|}{ Place of residence } & \multirow{3}{*}{$\begin{array}{l}\mathrm{X}^{2}=4.07 \\
\mathrm{P}=0.04\end{array}$} \\
\hline Rural & $40(58.8)$ & $39(76.5)$ & $79(66.4)$ & \\
\hline Urban & $28(41.2)$ & $12(23.5)$ & $40(33.6)$ & \\
\hline \multicolumn{4}{|l|}{ Ever been pregnant } & \multirow{3}{*}{$\begin{array}{l}\mathrm{X}^{2}=51.14 \\
\mathrm{P}=0.000\end{array}$} \\
\hline Yes & $59(86.8)$ & $11(21.6)$ & $70(58.8)$ & \\
\hline No & $9(13.2)$ & $40(78.4)$ & 49 (41.2) & \\
\hline \multicolumn{4}{|l|}{ Mothers education } & \multirow{5}{*}{$\mathrm{P}=0.03 * \mathrm{~F}$} \\
\hline Primary & $9(13.2)$ & $12(23.5)$ & $21(17.7)$ & \\
\hline Secondary & $21(30.9)$ & $21(41.2)$ & $42(35.3)$ & \\
\hline Post-secondary & $21(30.9)$ & $15(29.4)$ & $36(30.3)$ & \\
\hline No formal education & $4(25.0)$ & $3(5.9)$ & $20(16.8)$ & \\
\hline \multicolumn{4}{|l|}{ Mothers' education } & \multirow{3}{*}{$\begin{array}{l}X^{2}=1.00 \\
P=0.32\end{array}$} \\
\hline Less than secondary & $26(38.2)$ & $15(29.4)$ & $41(34.5)$ & \\
\hline Secondary and above & $42(61.8)$ & $36(70.6)$ & $78(65.5)$ & \\
\hline \multicolumn{4}{|l|}{ Fathers' education } & \multirow{5}{*}{$\mathrm{P}=0.004 * \mathrm{~F}$} \\
\hline Primary & $8(11.8)$ & $3(5.9)$ & $11(9.2)$ & \\
\hline Secondary & $17(25.0)$ & $27(52.9)$ & $44(37.0)$ & \\
\hline Post-secondary & $33(48.5)$ & $20(39.2)$ & $53(44.5)$ & \\
\hline No formal education & $10(14.7)$ & $1(2.0)$ & $11(9.2)$ & \\
\hline
\end{tabular}

Continued. 


\begin{tabular}{|c|c|c|c|c|}
\hline \multirow{2}{*}{ Characteristics } & \multicolumn{2}{|c|}{ Ever aborted } & \multirow{2}{*}{ Total n (\%) } & \multirow{2}{*}{$\begin{array}{l}\text { Statistical tests and } \\
\text { values }\end{array}$} \\
\hline & Yes n $(\%)$ & No n $(\%)$ & & \\
\hline \multicolumn{4}{|l|}{ Fathers' education } & \multirow{3}{*}{$\mathrm{P}=0.02 * \mathrm{~F}$} \\
\hline Below secondary & $18(26.5$ & $4(7.8)$ & $22(18.5)$ & \\
\hline Secondary and above & $50(73.5)$ & $47(92.2)$ & $97(81.5)$ & \\
\hline \multicolumn{4}{|l|}{ Mothers occupation } & \multirow{6}{*}{$\mathrm{P}=0.04$} \\
\hline Unemployed & $16(23.5)$ & $5(9.8)$ & $21(17.7)$ & \\
\hline Self-employed & $21(30.9)$ & $28(54.9)$ & $49(41.2)$ & \\
\hline Civil servant & $18(26.5)$ & $8(15.7)$ & $26(21.9)$ & \\
\hline Housewife & $12(17.7)$ & $8(15.7)$ & $20(16.8)$ & \\
\hline Others & $1(1.5)$ & $2(3.9)$ & $3(2.5)$ & \\
\hline
\end{tabular}

More than half of the respondents (58.8\%) had experienced an unwanted pregnancy prior to the study with most $(72.9 \%)$ of them having been pregnant once. The majority of the students $(61.4 \%)$ had used some form of contraceptive before they got pregnant. Condom $(39.5 \%)$ was the commonest contraceptive they used before getting pregnant followed by tablets/pills (23.3\%) (Table 2).

Most $(89.1 \%)$ of the respondents have heard of abortions while $68(57.1 \%)$ have had an abortion; with $67.6 \%$ and $16.2 \%$ having had the abortion just once and twice respectively.

The top 3 reasons for having an abortion were that they were schooling $(33.8 \%)$, too young $(25.9 \%)$ and to avoid shame or stigma associated with the pregnancy $(11.7 \%)$. The commonest methods of abortion used were dilatation and curettage (D and C) (40.2\%) and injections (29.3\%); while doctors $(34.1 \%)$, pharmacists $(25.6 \%)$ and nurses $(15.9 \%)$ performed most of the procedure. The majority of the procedures were performed in hospital (42.9\%) and pharmacies/chemist shops $(26.2 \%)$ while $11.9 \%$ were carried out in health centres; and were paid for by their partners (25\%) and friends (25\%) (Table 3).

The majority of the respondents, 68 (75\%) had complaints following the procedure; the top three being abdominal pain $(42.1 \%)$, bleeding $(26.3 \%)$ and fever $(19.3 \%)$. Twenty-four $(35.2 \%)$ received post-abortion contraceptive advice while more than half $(51.5 \%)$ were not given contraceptives after the abortion. There was a feeling of guilt by $24(35.3 \%)$ of respondents after the abortion while the $23.5 \%$ felt relieved even as $10(14.7 \%)$ regretted their action of having had an abortion (Table 4).

The place of residence (rural more than urban), $(\mathrm{p}=0.04)$, being pregnant more than once $(\mathrm{p}<0.001)$, mothers` level of education $(\mathrm{p}=0.03)$, fathers level of education $(\mathrm{p}=0.02)$ and mothers occupation $(\mathrm{p}=0.04)$ were significantly associated with respondents having an abortion (Table 5).

\section{DISCUSSION}

The prevalence of abortion from this study was $57.1 \%$. This is higher than the prevalence rate of unsafe abortion reported in some studies in the West African subregion. ${ }^{23-}$ ${ }^{25}$ It is however lower than the $74.2 \%$ reported in Western Nigeria by another author. ${ }^{26}$ The differences in prevalence may be a product of socioeconomic differences in the populations studied, the geographical location and the study designs as the studies in Ghana were among women of reproductive age groups of 1548years. ${ }^{23,24}$ while ours, like the Ethiopian study was carried out amongst adolescent secondary school students. $^{25}$ Admitting to having had an abortion is associated with some degree of stigmatization in our society where religion plays a major role in the day to day life. The assurance of confidentiality without inhibition provided may have aided the ease and freedom with which secret personal information on voluntary termination of pregnancy was reported by the participants.

Most of the respondents had heard of the term abortion and corroborates with findings from another study. ${ }^{22}$ This is in keeping with reasonable awareness of abortion by a reasonable proportion of the respondents. The prevalence of ever having an unwanted pregnancy in this study was higher than $31.1 \%$ reported in another study. ${ }^{24}$ Almost three-quarters of the respondents with history of abortion had done so once compared to $60.7 \%$; and more had 2 abortion compared to just $0.5 \%$ reported. ${ }^{22}$ This wide variation may be attributed to the possible stigma associated with admitting to repeated induced abortion which was avoided in this study by the assurance of strict confidentiality provided.

About $61.4 \%$ of respondent were using some form of contraceptives prior to the unwanted pregnancy and this is significantly higher than the $12 \%$ contraceptive usage recorded by a recent national survey and $21.5 \%$ reported by Lamina et al. ${ }^{27,28}$ The predominant contraceptive method from this study was the male condom which $39.5 \%$ used followed by oral contraceptive pills and the withdrawal method. However, the rate of unwanted pregnancy from this study was significantly high despite the rather relatively high usage of some form of contraception by respondents. This may have resulted from incorrect and inconsistent usage of the reported contraceptives by the respondents. The predominant reason for inducing an abortion from this study was schooling at $23.4 \%$. Schooling was also the reason given 
for voluntary termination of termination in other studies. $^{23,24}$ Secondary schools authorities in Nigeria usually expel pregnant students, so affected students opt to terminate their unplanned pregnancies in order to continue in school. Another study however implicated poverty, early sexual debut and ignorance as reasons for inducing abortion among teenagers, which none of this study respondents gave. ${ }^{29}$ This implies that several factors underlie the practice which may be related to socio-demographic and environmental characteristics.

Induced abortion from this study was predominantly performed by medical doctors; a pattern which was also reported and agreed to by researchers in other studies. ${ }^{24,30}$ However a study by Emechebe et al in Calabar, SouthSouth Nigeria reported quacks to be responsible for most induced abortion. ${ }^{31}$ The finding from this study may have been a product of erroneous perception of all male health care providers in and outside hospital settings as medical doctors. Hospitals were mentioned as facilities where most abortion of the abortions was performed in this study. No distinction was made in this study between Pubic(government-owned) and private hospitals/clinics, this is in agreement with previous studies which implicated private clinics. ${ }^{24,32}$ It is unlikely that a public hospital would be associated with voluntary termination of unwanted pregnancy for social reasons due to the restrictive abortion laws in Nigeria. ${ }^{2,3}$ It is also possible that respondents who had complications and post abortion care such as uterine evacuation for incomplete abortion in government hospitals may have listed such as part of initial procedure. It is not unusual for women with post-abortal complications like incomplete abortion to present in government hospitals where they are offered uterine evacuation and other post-abortion care.

Complaints were reported by the majority of this study respondents after the procedures at a rate that was significantly higher than that reported from a study in another African country. ${ }^{33}$ This may be attributed to Nigerian restrictive abortion laws which have driven the practice of induced abortion underground and unsafe..$^{2,3}$ Abdominal pain was reported as the predominant complaint in this study. This did not agree with findings from other studies which reported vaginal bleeding as the predominant compliant. ${ }^{22,25,32}$ This study respondents may have perceived pain as a more distressing condition compared to a mild vaginal bleeding, especially as analgesia and anesthesia may not have been utilized during these clandestine procedures. Other studies however reported sepsis followed by haemorrhage as predominant complications..$^{31,32}$ The variation in pattern, types and rates of different complications may be a result of varying expertise, personnel and environment where the abortions were carried out. Generally, This study respondents received some form of post abortion care that was comparable to that from another study in South West Nigeria, but specifically higher post-abortion

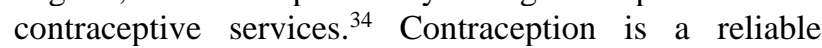
approach to reducing unwanted pregnancy and hence unsafe abortion. Its utilization has however been hindered by the erroneous association of contraceptive usage and sexual permissiveness.

The major determinants of the practice of abortion were place of residence (rural more than urban), being previously pregnant, educational status of both parents and the mother's occupation. Other studies found that being previously pregnant and having a previous history of induced abortion correlated positively with the practice of abortion. ${ }^{32,35}$ Other determinants or predictors of abortion found by other researchers include age, religion, being a Christian and employed and an experience of intimate partner violence. ${ }^{32,36-38}$ These wide variation in predictors seem to show that environment, personal experiences and society may be at play in the determination of the practice of abortion in a particular population.

Limitation of this study were information on termination of abortion amongst the students was based strictly on what was volunteered, hence subject to intentional dis/misinformation beyond our control. The information provided by respondents about their practice of abortion were not observed, hence could not be verified. The questionnaire had nothing on whether the pregnancies were confirmed or assumptions based on missed menses which may be common in this age group.

\section{CONCLUSION}

In conclusion, the reported prevalence of abortion in this study is high and above the National figures despite an apparently higher contraceptive prevalence rate. The procedure is unsafe and associated with high morbidity rate. This trend of unwanted pregnancy rates and a resultant high unsafe abortion rate despite contraceptive use indicate incorrect and inconsistent use of their chosen contraceptive methods. The major determinants of abortion practice were the socio-demographic characteristics of the parents. While recommending the need for accelerated reproductive health education in secondary schools in Nigeria, authors suggest that early sex education during the formative years should be provided by parents as these can influence subsequent perception, behaviour and later choices in schools. Authors also recommend replication of this study across other senatorial zones in the state, other states in the geopolitical area and the Nation at large. This authors hope will unearth the true picture of the practice of abortion among adolescents in Nigerian secondary schools.

\section{ACKNOWLEDGMENTS}

Authors wish to acknowledge with a sense of indebtedness the assistance and cooperation authors received from the teaching and non-teaching personnel, not forgetting the students that consented to the study in these Secondary schools. The authors also appreciate the 
contribution of Dr Ekanem, a Public health physician in the University of Uyo Teaching Hospital for the statistical analysis of the data obtained.

Funding: No funding sources

Conflict of interest: None declared

Ethical approval: The study was approved by the Institutional Ethics Committee

\section{REFERENCES}

1. Okagbue I. Pregnancy termination and the law in Nigeria. Stud Fam Plann. 1990;21:197-208.

2. Penal code (Northern states) Federal Provision Act, chapter 345 of the laws of the Federation of Nigeria (Revised edn); 1990:232-236.

3. Criminal Code Act, Chapter 77 of the laws of the federation of Nigeria (Revised ed); 1990:228230,297,309,328.

4. Grimes DA. Unsafe abortion: the silent scourge. $\mathrm{Br}$ Med Bullet. 2003;67(1):99-113.

5. WHO, safe abortion: Technical and Policy Guidance for Health Systems. World Health Organisation, Geneva, Switzerland, $2^{\text {nd }}$ edtion; 2012.

6. IPAS. Abortion law and policy in Nigeria: brriers to women access to safe and legal abortion. IPAS Garki, Abuja, FCT, Nigeria; 2015.

7. Bankole A, Oye-Adeniran BA, Singh S, Adewole IF, Wulf D, Sedgh G, et al. Unwanted Pregnancy and induced abortion in Nigeria: causes and consequences; 2006.

8. Oye-Adeniran BA, Adewole IF, Umoh AV, Ekanem EE, Gbadagesin A, Iwere N. Community based survey of unwanted pregnancy in southwestern Nigeria. Afr J Reprod Health. 2004;8:103-15.

9. Sedgh G, Singh S, Shah IH, Ahman E, Henshaw SK, Bankole A. Induced abortion: incidence and trends worldwide from 1995 to 2008. Lancet. 2012;379(9816):625-32.

10. Nwogu-Ikojo EE, Ezegwui HU. Abortion-related mortality in a tertiary medical centre in Enugu, Nigeria. J Obstet Gynaecol. 2007;27(8):835-37.

11. WHO. Preventing Unsafe abortion. June 2019. Available at: https://www.who.int/news-room/factsheets/detail/preventing-unsafe-abortion. Accessed on $05^{\text {th }}$ October 2019.

12. Monjok E, Smesny A, Ekabua JE, Essien EJ. Contraceptive practices in Nigeria: Literature review and recommendation for future policy decisions. Open Acc J Contracept. 2010;1:9.

13. World Health organisation. WHO. Adolescents: health risks and solutions. 2018. Available at: https://www.who.int/news-room/factsheets/detail/adolescents-health-risks-and-solutions. Accessed on $25^{\text {th }}$ August 2019.

14. Amazigo U, Silva N, Kaufman J, Obikeze DS. Sexual activity and contraceptive knowledge and use among in-school adolescents in Nigeria. Int Fam Plann Persp. 1997;23:28-33.
15. World Health Organization. Unsafe abortion: Global and regional estimates of the incidence of unsafe abortion and associated mortality in 2000. Geneva: World Health Organization; 2004.

16. WHO. World Health Statistics. Geneva: WHO press; 2009. Available at: https://www.who.int/gho/publications/world_health_ statistics/EN_WHS09_Full.pdf. Accessed on $1^{\text {st }}$ February 2020.

17. Korejo R, Noorani KJ, Bhutta S. Sociocultural determinants of induced abortion. J Coll Physicians Surg Pak. 2003;13(5):260-2.

18. Mote VC, Otupiri E, Hindin MJ. Factors associated with induced abortion mong women in Mohoe, Ghana. Afr J Reprod Health. 2010;14(4):1-15.

19. Ibom A (State, Nigeria) population statistics, chats, Maps. Available at: https://www.citypopulation.de/php/nigeriaadmin.php?adm1id=NGA003. Assessed on $21^{\text {st }}$ November 2019.

20. Bankole A, Adewole AF, Hussain R, Awolude O, Singh S, Akinyemi JO. The incidence of abortion in Nigeria. Inter Perspect Sex Reprod Health. 2015;41(4):170-81.

21. Charan J, Biswas T. How to calculate sample size for different study designs in medical research. Indian $\mathbf{J}$ Psychol Med. 2013;35(2):121-6.

22. Abiola AHO, Oke OA, Balogun MR, Olatona FA, Adegbesan-Omilabu MA. Knowledge, attitude, and practice of abortion among female students of two public senior secondary schools in Lagos Mainland Local Government Area, Lagos State. J Clin Sci. 2016;13:82-7.

23. Bongfen MC, Abanem EEB. Abortion practices among women in Buea: a socio-legal investigation. Pan Afr Med J. 2019;32:146.

24. Lamina MA. Prevalence and determinants of unintended pregnancy among women in southwestern Nigeria. Ghana Med J. 2015;49(3):187-94.

25. Rahel Y, Deriba A, Asrat M. Knowledge, attitude and practice towards induced abortion and associated factors among female students in Yebu secondary school, Jimma Zone, South west Ethiopia. Glob J Reprod Med. 2018;5(2):555-659.

26. Paluku JL, Kalisoke S, Julius W, Kiondo P. Knowledge and attitude about induced abortion among female youths attending Naguru female information centre, Kampala, Uganda. J Pub Health Epidemiol. 2013;5(4):178-85.

27. National population commission (NPC) (Nigeria) and ICF. 2018 Nigeria DHS Key Findings. Abuja, Nigeria and Rockville, Maryland, USA: NPC and ICF; 2019.

28. Lamina MA. Prevalence of abortion and contraceptive practice among women seeking repeat induced abortion in western Nigeria. J Preg. 2015:18

29. Fasaro AA, Agbana RD. Factors Influencing and dangers of criminal abortion among teenagers in a 
secondary school in Ekiti State, Nigeria. EJPMR. 2018;5(8):121-5.

30. Adewole IF, Oye-adeniran BA, Iwere N, Oladokun A, Gbadegesin A. Terminating an unwanted pregnancy: the economic implication in Nigeria. J Obstet Gynaecol. 2002;34:163-7.

31. Emechebe CI, Njoku CO, Udofia UM, Ukaga JT. Complication of induced abortion: Contribution to maternal mortality in a tertiary center of a low resource setting. Saudi J Health Sci. 2016;5:34-8.

32. Oyefabi AO, Nmadu AG, Yusuf MS. Prevalence, perceptions, consequences and determinants of induced abortion among students of the Kaduna State University, Northwestern Nigeria. J Med Trop. 2016;18:86-92.

33. Induced abortion and postabortion care among adolescents in Ethiopia. Available at: https://www.guttmacher.org/sites/default/files/factsh eet/adolescent-abortion-ethiopia.pdf. Accessed on $13^{\text {th }}$ December 2019.

34. Awoyemi BO, Novignon J. Demand for abortion and post abortion care in Ibadan, Nigeria. Health Econ Rev. 2014;4:3.

35. Tilahun F, Dadi AF, Shiferaw G. Determinants of abortion among clients coming for abortion service at felegehiwot referral hospital, Northwest Ethiopia: a case control study. Contracept Reprod Med. 2017;2:11.

36. Alemayehu M, Yebyo H, Medhanyie AA, Bayray A, Fantahun M, Goba GK. Determinants of repeated abortion among women of reproductive age attending health facilities in Northern Ethiopia: a case-control study. BMC Public Health. 2017; $17: 188$.

37. Dickson KS, Adde KS, Ahinkorah BO. Socioeconomic determinants of abortion among women in Mozambique and Ghana: evidence from demographic and health survey. Arch Public Health. 2018;76:37.

38. Yaya S, Amouzou A, Uthman OA, Ekholuenetale M, Bishwajit G, Udenigwe $\mathrm{O}$, et al. Prevalence and determinants of terminated and unintended pregnancies among married women: analysis of pooled cross-sectional surveys in Nigeria. BMJ Glob Health. 2018;3:e000707.

Cite this article as: Abah MG, Bassey EE, Edu EB, Ovieb OD. Unsafe abortion among secondary school girls in a local authority in South-South Nigeria. Int $\mathbf{J}$ Reprod Contracept Obstet Gynecol 2020;9:3547-56. 